\title{
EFEK TERATOGENIK EKSTRAK RIMPANG RUMPUT TEKI (Cyperus rotundus L.) TERHADAP JUMLAH FETUS, PANJANG EKSTREMITAS DEPAN DAN BELAKANG, SERTA MALFORMASI FETUS MENCIT (Mus musculus L.)
}

\section{TERRATOGENITY EFFECT OF RHIZOME NUTGRASS (Cyperus rotundus L.) EXTRACT TOWARD FETUS NUMBER, ANTERIOR-POSTERIOR EXTREMITIES' LENGTH, AND MALFORMATION OF MICE FETUS (Mus musculus L.)}

\author{
Faizatin Nadya Roza ${ }^{1 *}$, Nuning Nurcahyani ${ }^{1}$, Hendri Busman $^{1}$ \\ ${ }^{1} J u r u s a n$ Biologi, FMIPA Universitas Lampung \\ Jl. Prof. Dr. Sumantri Brojonegoro No. 1 Bandar Lampung 35145 \\ *e-mail: faizatinnadya@yahoo.com
}

\begin{abstract}
ABSTRAK
Rumput teki (C. rotundus) mengandung senyawa yang zat-zat aktif yang dapat mempengaruhi proses hormonal jika digunakan secara langsung sehingga dapat memberikan efek samping khususnya jika dikonsumsi oleh wanita hamil. Pada periode organogenesis, embrio sangat sensitif terhadap masuknya suatu zat ke dalam tubuhnya. Penelitian yang dilakukan pada 23 Desember 2015 hingga 22 Januari 2016 di Laboratorium Zoologi dan Laboratorium Kimia Organik FMIPA Universitas Lampung bertujuan untuk mengetahui pengaruh teratogenik dari ekstrak rimpang rumput teki terhadap jumlah fetus, pertumbuhan panjang ekstremitas depan dan belakang, serta malformasi (kecacatan) fetus mencit (M. musculus L.) secara anatomi. Dua puluh mencit betina dibagi menjadi 4 kelompok. Ekstrak diberikan secara oral pada tiga kelompok perlakuan dengan dosis $45 \mathrm{mg} / 40 \mathrm{gBB}$ (B); $90 \mathrm{mg} / 40 \mathrm{gBB}$ (C); dan $135 \mathrm{mg} / \mathrm{gBB}$ (D), dalam 0,4 $\mathrm{mL}$ aquabides sedangkan satu kelompok tanpa ekstrak (A) sebagai kontrol. Perlakuan diberikan pada hari ke-6 samapai ke-13 kehamilan (periode organogenesis). Hasil menunjukkan bahwa pemberian ekstrak rimpang rumput teki tidak mengurangi jumlah fetus yang dikandung namun menyebabkan kematian pada beberapa fetus. Selain itu, ekstrak rimpang rumput teki tidak menghambat pertumbuhan panjang ekstremitas depan fetus tetapi menghambat pertumbuhan panjang ekstremitas belakang fetus secara signifikan terhadap kontrol. Pemberian ekstrak rimpang rumput teki menyebabkan perbedaan panjang antara ukuran ekstremitas depan dan belakang kanan dibanding bagian kirinya serta menyebabkan malformasi fetus dan salah satu induk mencit mati akibat pemberian ekstrak.
\end{abstract}

Kata Kunci: rimpang rumput teki (Cyperus rotundus L.), ekstremitas depan dan belakang, malformasi, mencit (Mus musculus L.)

\section{ABSTRACT}

Nutgrass contain compounds active substances that can affect hormonal processes if used directly so that it may give side effects, especially if taken by pregnant women. In the period of organogenesis, the embryo is very sensitive to the inclusion of a substance into their body. This research has been conducted from December 23rd, 2015 until January 22nd, 2016 in Zoology Laboratory and Organic Chemistry Laboratory Lampung University. It was done to examine the teratogenic effect from rhizome nutgrass (C. rotundus L.) toward fetus number, the growth of anterior and posterior extremities length, and other malformation of mice fetus (M. musculus L.) anatomically. Twenty female mice were randomly divided into four groups. The extract was given orally to three treatment groups with dosage 45 $\mathrm{mg} / 40 \mathrm{gBW}$ (B); $90 \mathrm{mg} / 40 \mathrm{grBW}$ (C); and $135 \mathrm{mg} / 40 \mathrm{grBW}$ (D) in $0.4 \mathrm{ml}$ aquabidest whereas one group without extract as control. Treatment was given from day 6 to day 13 of gestation (organogenesis period). The results showed that giving rhizome nutgrass extract didn't deduct the fetus number which gestated but caused the mortality to several fetuses. In addition, rhizome nutgrass extract didn't obstruct the growth of anterior extremities fetus length but obstruct the growth of posterior extremities fetus length marked by significant difference toward control groups. Giving rhizome nutgrass extract caused the anterior and posterior extremities have length differences between its right and its left as caused as malformation existences to fetus and one of mice mother died because of giving extract.

Keyword: rhizome nutgrass extract (Cyperus rotundus L.), anterior-posterior extremities, malformation, mice.

PENDAHULUAN

Indonesia merupakan negara tropis yang

banyak ditumbuhi tanaman sebagai sumber bahan obat. Masyarakat Indonesia sudah menggunakan sumber bahan obat dari alam sebagai obat tradisional dari 
nenek moyang secara turun- temurun (Agusta, 2001). Rumput teki merupakan herba menahun yang tumbuh liar dan kurang mendapat perhatian, padahal tanaman ini merupakan tanaman yang dapat dilihat di berbagai tempat. Ciri khas dari tanaman ini adalah memiliki rimpang yang ternyata memiliki banyak manfaat. Menurut Murnah (1995), rimpang rumput teki ini mengandung komponen-komponen kimia antara lain minyak atsiri, alkaloid, flavonoid, polifenol, resin, amilum tanin, triterpen dan seskuiterpen. Tanaman tersebut merupakan tanaman yang banyak digunakan sebagai obat gangguan menstruasi yang memberikan pengaruh terhadap siklus haid. Bila ditinjau dari zatzat aktif yang terdapat pada tanaman tersebut, bila digunakan sebagai obat peluruh haid dan kontrasepsi secara langsung dapat mempengaruhi proses hormonal sehingga dapat memberikan efek samping apabila dikonsumsi oleh wanita hamil. Pada periode organogenesis, embrio sangat sensitif terhadap masuknya suatu zat ke dalam tubuhnya. Ekstremitas depan dan belakang mencit hampir mirip dengan manusia. Perlunya dilakukan pengamatan terhadap ekstremitas dikarenakan pada saat periode organogenesis, ekstremitas depan merupakan organ luar yang pertama kali terbentuk. Sedangkan pengamatan pada ekstremitas belakang dilakukan sebagai perbandingan terhadap ekstremitas depan. Sehingga penelitian ini bertujuan untuk mengetahui pengaruh teratogenik dari ekstrak rimpang rumput teki (Cyperus rotundus L.) terhadap pertumbuhan panjang ekstremitas depan dan belakang fetus mencit (Mus musculus L.) secara anatomi.

\section{BAHAN DAN METODE}

Penelitian ini dilaksanakan di Laboratorium Kimia Organik, Jurusan Kimia FMIPA Unila untuk pembuatan eksrtak rimpang teki dan Laboratorium Zoologi, Jurusan Biologi FMIPA Unila untuk tempat pemberian perlakuan pada mencit dan pengamatann pada 23 Desember 2015 hingga 22 Januari 2016.

Alat dan bahan yang digunakan dalam penelitian ini adalah kandang mencit yang berukuran $50 \times 30 \mathrm{~cm}$, tempat makan dan minum mencit sebanyak 20 unit, seperangkat alat bedah, sondae lambung, kertas label, kertas millimeter blok, jangka sorong, mikrometer sekrup, 20 ekor mencit betina dan jantan yang berumur 3-4 bulan dengan berat sekitar 40 gram, alkohol 96\%, kapas, kloroform, makanan mencit, aquabidest, aquadest, air dan ekstrak rimpang rumput teki.

\section{Persiapan Kandang dan Hewan Uji}

Hewan uji diaklimatisasi selama 10 hari dalam kondisi laboratorium $\mathrm{Di}$ dalam kandang yang telah disiapkan, ditempatkan satu ekor mencit jantan dan satu ekor mencit betina serta diberi makan dan air minum secukupnya setiap hari.

\section{Pembuatan Ekstrak Rimpang Rumput Teki}

Rimpang rumput teki yang telah diperoleh dibersihkan dan dijemur hingga kering; lalu 
digiling hingga menjadi serbuk. Serbuk tersebut dibuat ekstrak dengan pelarut ethanol dengan cara soklet. Ekstrak dipekatkan menggunakan rotary evaporator dengan suhu $35{ }^{\circ} \mathrm{C}$ dan kecepatan 60 rpm selama 1 jam (Busman, 2013).

\section{Pemberian Perlakuan}

Dua puluh ekor mencit betina yang hamil dibagi dalam empat kelompok yakni satu kelompok sebagai kontrol dan tiga kelompok lainnya adalah kelompok yang diberi perlakuan. Masing-masing kelompok terdiri dari lima ekor mencit sebagai pengulangan.Pemberian ekstrak rimpang rumput teki pada penelitian ini dilakukan secara oral dengan menggunakan sondae lambung untuk mempermudah masuknya ekstrak ke dalam tubuh mencit betina yang hamil melalui saluran pencernaan sehingga ekstrak cepat masuk ke dalam embrio melalui tali plasenta sehingga persen pemberian ekstrak digunakan adalah $1 \%$. Dosis yang diberikan kepada setiap mencit betina yang hamil adalah terdiri dari empat kelompok dimana satu kelompok kontrol diperlakukan dengan diberi $0.4 \mathrm{ml}$ aquabides (A), dan tiga kelompok perlakuan diberikan dosis 45 $\mathrm{mg} / 40 \mathrm{gBB}$ (B), $90 \mathrm{mg} / 40 \mathrm{gBB}$ (C), dan $135 \mathrm{mg} / 40$ gBB $(D)$ dalam $0,4 \mathrm{ml}$ aquabides.

\section{Laparaktomi}

Pada hari ke-18 kehamilan, semua mencit betina yang hamil dimasukkan ke dalam desikator. Laparaktomi dilakukan untuk mengeluarkan fetus dengan cara membedah pada bagian abdomen ke arah atas sampai terlihat uterus yang berisi fetus. Fetus kemudian dikeluarkan dengan memotong uterus dan plasenta untuk selanjutnya diamati. Fetus dari masingmasing mencit dikeringkan dengan tissue dan dihitung jumlah yang hidup dan mati, serta diamati ada atau tidaknya kelainan secara visual (Wilson dan Warkany (1975) dalam Setyawati, 2009).

\section{Fiksasi dan Pengamatan Struktur}

\section{Anatomi}

Setelah diamati ada atau tidaknya malformasi pada fetus mencit, dilakukan pengamatan struktur anatomi pada penelitian ini adalah dengan melihat dan mengukur panjang penulangan ekstremitas depan dan belakang fetus. Pengukuran panjang dilakukan dengan menggunakan kertas millimeter block dan alat ukur berupa mikrometer sekrup untuk mempertajam ketelitian ukuran panjang.

\section{Analisis Data}

Data yang diperoleh terdiri dari panjang ekstremitas depan dan belakang yang dianalisis secara statistik dengan menggunakan ANOVA (analysis of variant) dan diuji lanjut dengan menggunakan uji BNT (Beda Nyata Terkecil) pada taraf uji a $=5 \%$. Data jumlah fetus dan malformasi yang ditemukan dianalisis secara deskriptif.

\section{HASIL DAN PEMBAHASAN}

Berdasarkan hasil penelitian, data yang diperoleh terdiri dari jumlah fetus tiap 
kelompok, panjang ekstremitas depan dan belakang fetus mencit baik kanan dan kirinya, serta malformasi fetus.

\section{Jumlah Fetus Mencit}

Tabel 1. Jumlah fetus mencit dari induk yang diinduksi ekstrak rimpang rumput teki

\begin{tabular}{llccc}
\hline & \multirow{2}{*}{ Kelompok } & \multirow{2}{*}{$\begin{array}{c}\text { Jumlah } \\
\text { Induk }\end{array}$} & \multicolumn{2}{c}{$\begin{array}{c}\text { Jumlah Fetus } \\
\text { (Ekor) }\end{array}$} \\
\cline { 4 - 5 } & Perlakuan & (Ekor) & Hidup & Mati \\
\hline 1 & A & 5 & 25 & - \\
2 & B & 5 & 24 & - \\
3 & C & 5 & 33 & 5 \\
4 & D & 4 & 19 & - \\
\hline
\end{tabular}

Ket.: rata-rata setiap induk melahirkan 49 ekor anak mencit. A: kontrol; B: dosis $45 \mathrm{mg}$; C: dosis $90 \mathrm{mg}$; D: dosis $135 \mathrm{mg}$.

\section{Mangkoewidjojo dan Smith} menyatakan bahwa rerata jumlah anak mencit yang lahir adalah 6 ekor, meskipun mencit dapat melahirkan 15 ekor per kelahiran. Pada penelitian ini, tanpa membedakan kelompok perlakuan dan kontrol, rata-rata tiap induk mencit melahirkan 4-9 ekor anak. Ini sesuai dengan pernyataan Mangkoewidjojo dan Smith (1988) menyatakan bahwa rata-rata jumlah anak yang dilahirkan induk mencit adalah 6 ekor.

Besarnya jumlah anak yang dilahirkan dipengaruhi oleh jenis hewan, umur induk, musim kelahiran, makanan, faktor persilangan genetik dan kondisi lingkungan. Faktor lingkungan yang sangat mempengaruhi jumlah kelahiran antara lain kualitas dan kuantitas pakan yang diberikan pada induk, musim kawin, jumlah sel telur yang dihasilkan serta tingkat kematian embrio yang sangat berpengaruh terhadap jumlah anak yang dilahirkan (Somala, 2006). Apabila hewan kekurangan zat makanan pada saat kehamilan, maka pengambilan zat makanan oleh embrio yang sedang tumbuh akan merusak badannya. Kematian fetus dalam uterus atau kelahiran anak yang lemah dapat terjadi.

Jumlah fetus hidup menurun dengan meningkatnya dosis ekstrak yang diberikan. Kematian fetus tidak terjadi pada setiap induk karena kemampuan yang berbeda dari masing-masing induk dalam memetabolisir ekstrak rimpang rumput teki (Setyawati, 2009). Diduga fetus yang mati sejak dalam kandungan belum selesai mengalami perkembangan sehingga memiliki ukuran lebih kecil dibanding fetus yang lahir dalam keadaan hidup. Selain ukurannya yang lebih kecil dibandigkan dengan fetus yang hidup, kemampuan untuk tumbuh dan berkembang menjadi semakin lemah karena tingginya dosis ekstrak rimpang rumput teki yang diberikan. Akibat dari tingginya dosis ekstrak rimpang rumput teki yang diberikan, terdapat terdapat 1 ekor induk yang mati sebelum saat kelahiran atau pembedahan pada kelompok dosis $135 \mathrm{mg} / 0.4 \mathrm{ml}$ aquabidest. 


\section{Ekstremitas Depan Fetus Mencit}

Tabel 2. Rata-rata panjang ekstremitas depan fetus mencit

\begin{tabular}{lccc}
\hline \multirow{2}{*}{ No. } & Kelompok & \multicolumn{2}{c}{ Panjang Ekstremitas Depan Fetus Mencit } \\
\cline { 3 - 4 } & Perlakuan & Kanan & Kiri \\
\hline 1 & A & $3.4550 \pm 0.37599^{\mathrm{a}}$ & $3.4550 \pm 0.37599^{\mathrm{a}}$ \\
2 & $\mathrm{~B}$ & $3.4975 \pm 0.35132^{\mathrm{a}}$ & $3.4525 \pm 0.45434^{\mathrm{a}}$ \\
3 & $\mathrm{C}$ & $3.2175 \pm 0.44192^{\mathrm{a}}$ & $3.3575 \pm 0.48849^{\mathrm{a}}$ \\
4 & $\mathrm{D}$ & $3.5900 \pm 0.18129^{\mathrm{a}}$ & $3.4456 \pm 0.15650^{\mathrm{a}}$ \\
\hline
\end{tabular}

Ket.: A: kontrol; B: dosis $45 \mathrm{mg}$; C: dosis $90 \mathrm{mg}$; D: dosis $135 \mathrm{mg}$.
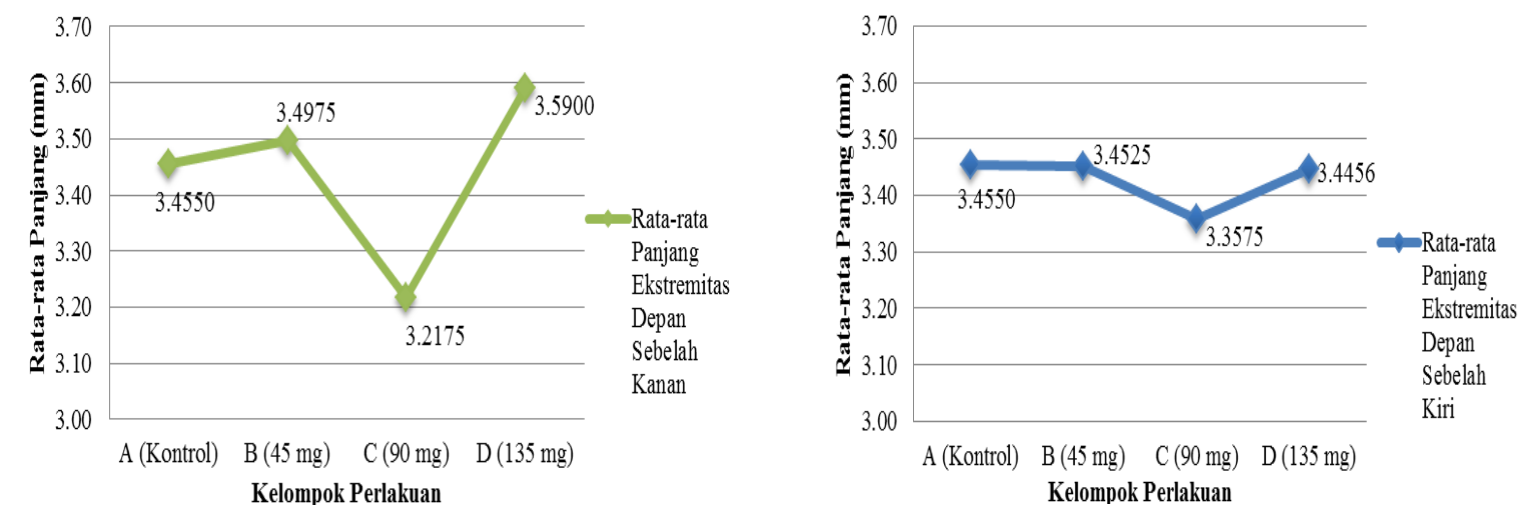

Gambar 1. Rata-rata panjang ekstremitas depan fetus mencit

Berdasarkan hasil pengamatan, pemberian ekstrak rimpang rumput teki tidak memberikan pengaruh terhadap pertumbuhan panjang ekstremitas depan fetus mencit. Hal ini dapat dilihat pada Tabel 2 dimana rata - rata panjang ekstremitas depan fetus pada tiap kelompok perlakuan ( $B, C$, dan $D)$ tidak memberikan hasil berupa perbedaan yang signifikan terhadap kelompok yang tidak diberikan perlakuan atau kelompok kontrol (A).

Akan tetapi, terdapat perbedaan ukuran panjang antara ekstremitas depan sebelah kanan dan panjang ekstremitas sebelah kiri pada tiap kelompok perlakuan $(B, C$, dan D). Hal ini membuktikan bahwa pemberian ekstrak rimpang rumput teki memberikan pengaruh teratogenik terhadap panjang ekstremitas depan karena ekstrak rimpang rumput teki secara nyata mempengaruhi perkembangan fetus dan menimbulkan efek yang berubah-ubah mulai dari kematian sampai kelainan bentuk (malformasi) dan hambatan pertumbuhan (Young, 2001).

Selain itu, pada pemberian dosis 90 $\mathrm{mg} / 0.4 \mathrm{ml}$ akubiades (kelompok perlakuan C), ekstremitas depan fetus mencit mengalami pengurangan ukuran panjang apabila dibandingkan dengan kelompok kontrol (Gambar 1). 


\section{Ekstremitas Belakang Fetus Mencit}

Tabel 3. Rata-rata panjang ekstremitas belakang fetus mencit

\begin{tabular}{clcc}
\hline \multirow{2}{*}{ No. Kelompok Perlakuan } & \multicolumn{2}{c}{ Panjang Ekstremitas Belakang Fetus Mencit } \\
\cline { 3 - 4 } & & Kanan & Kiri \\
\hline 1 & A (Kontrol) & $4.2600 \pm 0.30670^{\mathrm{a}}$ & $4.2600 \pm 0.30670^{\mathrm{a}}$ \\
2 & B (Dosis 45 mg) & $3.4150 \pm 0.13178^{\mathrm{b}}$ & $3.4400 \pm 0.22672^{\mathrm{b}}$ \\
3 & C (Dosis 90 mg) & $3.5425 \pm 0.20353^{\mathrm{bc}}$ & $3.5875 \pm 0.17933^{\mathrm{bc}}$ \\
4 & D (Dosis 135 mg) & $3.5150 \pm 0.40249^{\mathrm{bd}}$ & $3.7033 \pm 0.12897^{\mathrm{bd}}$ \\
\hline
\end{tabular}

Ket : perbedaan huruf superskrip pada tabel menunjukkan adanya perbedaan nyata yang signifikan pada tiap perlakuan setelah dilakukan uji BNT.
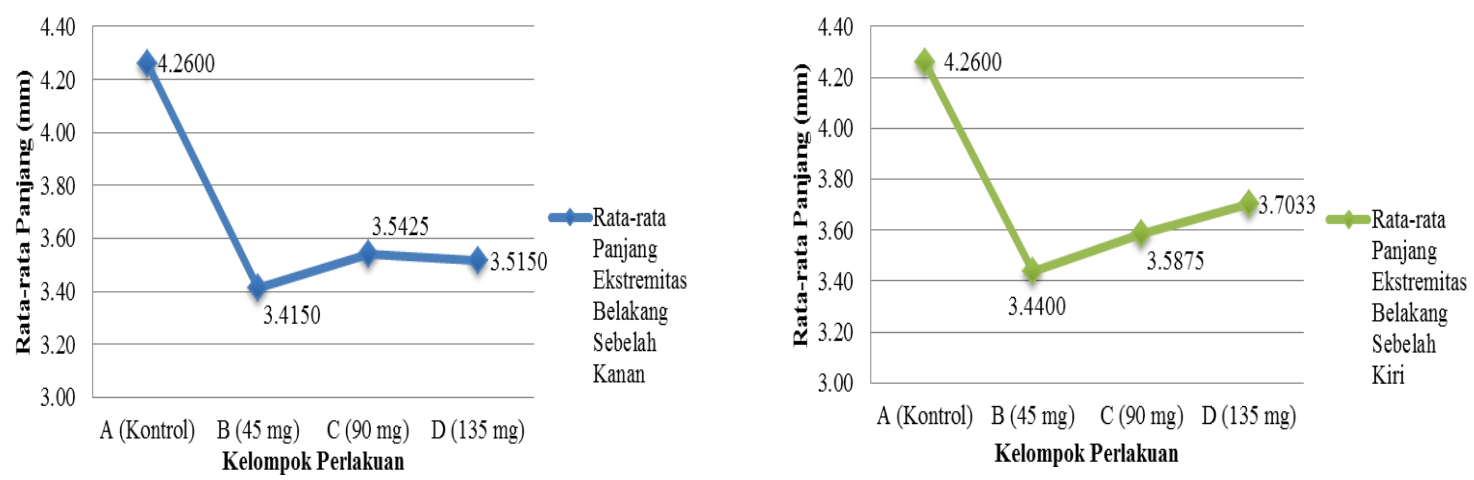

Gambar 2. Rata-rata panjang ekstremitas belakang fetus mencit.

Pada Tabel 3, kelompok perlakuan yang diberi ekstrak rimpang rumput teki $(\mathrm{B}, \mathrm{C}$, dan D) menunjukkan perbedaan yang signifikan terhadap kelompok kontrol (A). Setelah dilakukan uji lanjut, semua kelompok perlakuan menunjukkan hasil yang berbeda nyata dengan kelompok kontrol. Namun antar tiap kelompok perlakuan tidak menunjukkan hasil yang berbeda nyata. Selain itu, panjang antara ekstremitas belakang sebelah kanan dan ekstremitas ekstremitas sebelah kiri pada tiap kelompok perlakuan (B, C, dan D) berbeda-beda bila dibandingkan dengan kelompok kontrol yang memiliki panjang ekstremitas yang sama antara kanan dan kirinya. Oleh karena itu, pemberian ekstrak rimpang rumput teki memberikan pengaruh teratogenic terhadap ekstremitas belakang berupa penurunan pertumbuhan panjang dan perbedaan ukuran ekstremitas belakang kanan dan kiri fetus mencit.

Hambatan pertumbuhan dan perkembangan tulang yang terjadi dalam penelitian ini dimungkinkan berkaitan dengan adanya hambatan mitosis pada sel-sel yang berperan dalam osteogenesis, yaitu kondrosit dan osteoblas. Hambatan terjadi melalui mekanisme cAMP yang mengontrol mitosis. Pozner (1986) menyatakan bahwa pertumbuhan sel berhubungan dengan konsentrasi cAMP. Adanya reduksi konsentrasi cAMP biasanya diikuti dengan meningkatnya aktivitas pertumbuhan, sebaliknya peningkatan konsentrasi cAMP di dalam sel dan jaringan akan menurunkan tingkat pertumbuhan sel, dan pada peningkatan konsentrasi cAMP yang tinggi dapat menyebabkan hambatan akselerasi 
pertumbuhan. Kenyataan ini terjadi karena rimpang rumput teki yang diberikan ke induk mencit melalui oral mampu melewati tali plasenta dan masuk ke dalam cairan intraseluler (Sawynok dan Yaksh (1993) dalam Santoso, 2006).

Menurut Robbinson (1995), senyawa flavonoid yang terkandung dalam rimpang rumput teki dapat menghambat aktivitas enzim fosfodiesterase yang menghidrolisis CAMP, sehingga mengakibatkan peningkatan konsentrasi cAMP dalam sel dan jaringan fetus (Santoso, 2004).

\section{Malformasi Pada Fetus MencitPada} penelitian ini, ditemukan beberapa fetus yang mati pada saat sebelum kelahiran. Fetus mati tersebut ditemukan pada induk mencit yang diberikan ekstrak pada dosis $90 \mathrm{mg} / 0.4 \mathrm{ml}$ akuades (kelompok C). Fetus mati ini kemungkinan disebabkan kematian sel-sel pada tahap akhir proliferasi sehingga hanya sebagian sel yang dapat diperbaiki dan pada saat pembedahan proses resorbsi oleh induk belum sempurna sehingga biasanya fetus yang mati ditemukan dalam keadaan cacat. Fetus yang hidup mempunyai daya tahan paling tinggi terhadap zat asing yang masuk. Fetus ini mampu mengadakan perbaikan kembali sel-sel yang rusak atau mati dengan sel yang baru sehingga memungkinkan fetus untuk bertahan hidup. Kematian intrauterus seperti resorbsi dan fetus mati kemungkinan dapat pula disebabkan oleh adanya kontraksi otot uterus selama masa organogenesis akibat pemberian ekstrak rimpang rumput teki (Sumastuti, 2004).



(a)

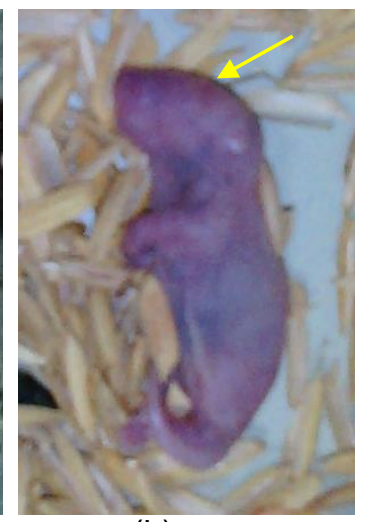

(b)
Gambar 3. Perbandingan gambar fetus yang hidup dan mati. Keterangan : A.Fetus yang lahir hidup, B. Fetus yang lahir mati dan mengalami hemoragi pada bagian kepala (yang ditunjuk anak panah)

Pada salah satu fetus yang mati sebelum kelahiran atau pada saat pembedahan dilakukan, ditemukan adanya salah satu fetus yang mengalami kelainan berupa hemoragi. Menurut Price dan Wilson 1984, Hemoragi merupakan keluarnya darah dari sistem kardiovaskuler, disertai penimbunan dalam ruangan atau jaringan tubuh (Setyawati, 2009).

Kelainan berupa hemoragi kemungkinan terjadi karena ekstrak rimpang rumput teki diberikan berulangkali pada dosis cukup tinggi hingga konsentrasinya tinggi dalam darah sehingga terjadi ketidakseimbangan osmotik. Dosis tertinggi pada penelitian ini adalah $135 \mathrm{mg} / 0.4 \mathrm{ml}$ akuabides (kelompok D). Adanya penyebab pemberian dosis tinggi ini juga menyebakan salah satu induk mencit sebelum saat pembedahan atau saat kelahiran. 
Pada keadaan normal, embrio berkembang dalam cairan amnion yang isotonis dengan cairan tubuh. Menurut Wilson (1975), zat asing dalam jaringan dapat mengubah tekanan osmosis. Ketidakseimbangan osmotik dapat disebabkan gangguan tekanan dan viskositas cairan pada bagian embrio yang berbeda, antara plasma darah dan ruang ekstra-kapiler. Perbedaan ini menyebabkan pembuluh darah pecah dan terjadi hemoragi (Setyawati, 2009).

Kecacatan visual lainnya adalah adanya fetus mengalami pembentukan kepala yang tidak sempurna dan ekor yang mebengkok apabila diandingkan dengan kontrol (Gambar 2).

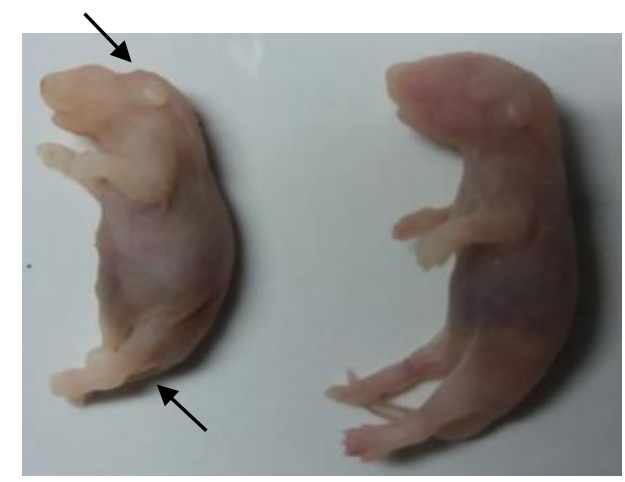

Gambar 4. Perbandingan kecacatan fetus. Keterangan : A. Fetus yang mengalami kecacatan (bentuk kepala tidak sempurna dan ekor bengkok), $B$. Fetus normal

Senyawa aktif seperti alkaloid dan saponin yang terkandung di dalam ekstrak rimpang rumput teki dimungkinkan dapat memacu kontraksi otot polos uterus (Sa'roni dan Wahyoedi, 2002). Adanya tekanan mekanik berupa kontraksi otot polos uterus tersebut pada masa kehamilan dapat menyebabkan gangguan pada janin dan juga dapat mengubah arah pertumbuhan tulang (Ritter, 1977).

Individu yang mengalami malformasi (kecacatan) umumnya lebih kecil dibandingkan individu normal. Oleh karena itu, sebelum menyatakan adanya abnormalitas pada suatu individu maka berat hewan yang diuji harus dibandingkan dulu dengan kontrol untuk memastikan bahwa hambatan pertumbuhan suatu organ merefleksikan hambatan pertumbuhan secara umum. Beberapa agen teratogen juga dapat mengakibatkan kelainan visceral maupun skeletal tanpa menunjukkan adanya kelainan morfologi eksternal (Santoso, 2006).

\section{KESIMPULAN DAN SARAN}

Kesimpulan yang dapat diambil dari penelitian ini adalah pemberian ekstrak rimpang rumput teki (Cyperus rotundus L.) tidak mengurangi jumlah fetus yang dikandung namun menyebabkan kematian pada beberapa fetus yang dilahirkan oleh induk mencit (Mus musculus L.). Selain itu, ekstrak rimpang rumput teki tidak menghambat pertumbuhan panjang ekstremitas depan fetus mencit namun menghambat pertumbuhan panjang ekstremitas belakang fetus mencit (Mus musculus L.) ditandai dengan adanya perbedaan nyata yang signifikan terhadap kontrol. Ekstrak rimpang rumput teki juga menyebabkan perbedaan ukuran panjang antara kanan dan kiri pada ekstremitas depan dan belakang serta menyebabkan adanya malformasi pada fetus dan salah 
satu induk mencit mati akibat pemberian ekstrak.

Saran yang dapat diberikan dari penelitian ini adalah perlu dilakukan penelitian lebih lanjut tentang senyawa - senyawa pada ekstrak rimpang rumput teki (Cyperus rotundus L.) yang sekiranya berpengaruh besar terhadap pertumbuhan dan perkembangan fetus mencit (Mus musculus L.) dan mengkaji ulang mengenai dosis pemberian ekstrak rimpang rumput teki sehingga dapat menentukan dosis yang sangat berpengaruh terhadap terhadap pertumbuhan dan perkembangan fetus mencit (Mus musculus L.)

\section{DAFTAR PUSTAKA}

Agusta, A. 2001. Awas! Bahaya Tumbuhan Obat. [internet]. (diunduh pada 19 Maret 2016). Tersedia pada http://www.indomedia.com/

Busman, H. 2013. Histologi Ulas Vagina dan Waktu Siklus Estrus Masa Subur Mencit Betina Setelah Pemberian Ekstrak Rimpang Rumput Teki. Prosiding Semirata FMIPA Universitas Lampung.

Mangkoewidjojo dan Smith. 1988. Pemeliharaan, Pembiakan, dan Penggunaan Hewan Percobaan di Daerah Tropis. UI Press. Jakarta

Murnah. 1995. Pemeriksaan Kualitatif dan Kuantitatif Minyak Atsiri Dan Tannin Dalam Umbi Teki. Jurnal Kedokteran Diponegoro. 30 $(3,4)$. 234-238.

Pozner, J.A.B., A.E. Papatestas, R. Fagerstrom, I. Schwartz, J.
Saevitz, M Feinberg, A.H. Anfsea. 1986. Association of tumor differentiation with caffein in intake in woman with breast cancer.Surgery. 100(3). 482486.

Price, S.A., and L.M. Wilson. 1984. Patofisiologi, CV EGC, Jakarta, hal.468.

Robbinson, T. 1995. The Basic of Higher Plants. $6^{\text {th }}$ Edition. Terjemahan.

Ritter, E.J. 1977. Altered biosynthesys In: Wilson, J.G. and F.C. Fraser (eds.) Hand Book of Teratology. Vol.2. New York:Plenum Press.

Sa'roni dan Wahyoedi. 2002. Pengaruh Infuse Rimpang Cyperus rotundus L. Terhadap Siklus Estrus dan Bobot Uterus Pada Tikus Putih. Jurnal Bahan Alam Indonesia. Jakarta. HIm 45-47.

Santoso, H.B. 2004. Kelainan Struktur Anatomi Skeleton Fetus Mencit Akibat Kafein. Jurnal Bioscientiae. 1 (2):23-30.

Santoso, H.B. 2006. Pengaruh Kafein terhadap Penampilan Reproduksi dan Perkembangan Skeleton Fetus Mencit (Mus musculus L). Jurnal Biologi. X: 39-48.

Sawynok, J. dan Yaksh, T.L. 1993. Caffeine as an analgesic adjuvant : A review of pharmacology \& mechanism of action. Pharmacological Reviews 45 1: 4546.

Setyawati, I. 2009. Morfologi Fetus Mencit (Mus musculus L.) Setelah Pemberian Ekstrak Daun Sambiloto (Andrographis paniculata Nees). Jurnal Biologi. XIII (2) : 41-44

Somala, L. 2006. Sifat Reproduksi Mencit (Mus musculus) Betina yang Mendapat Pakan Tambahan Kemangi (Ocimum basilicum) Kering. Skripsi. Program Studi Teknologi Produksi Ternak 
Fakultas Peternakan, Institut Pertanian Bogor

Sumastuti, R. 2004. Pengaruh Infus Daun dan Buah Makuta Dewa Pada Rahim Marmot. Medika 30(1). 16-23.

Toelihere, M. R. 1979. Fisiologi Reproduksi pada Ternak. Penerbit Angkasa, Bandung.

Wilson, J.G. and J. Warkany. 1975. Teratology Principles and Techniques. University of Chicago Press. Chicago IL.

Young, V. S. L. 2001. "Teratogenicity and Drugs in Breast Milk". In: KodaKimble, Anne, M.; and Bing, M. 2001. Applied Therapeutics: the Clinical Use of Drugs. Lippincott Williams and Wilkins. 